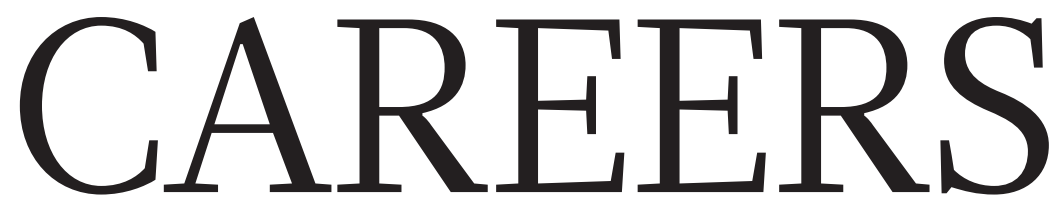

TURNING POINT A move from China to

America pays off for epigeneticist p.179
@NATUREJOBS Follow us on Twitter for the latest news and features go.nature.com/e492gf
NATUREJOBS For the latest career

listings and advice www.naturejobs.com

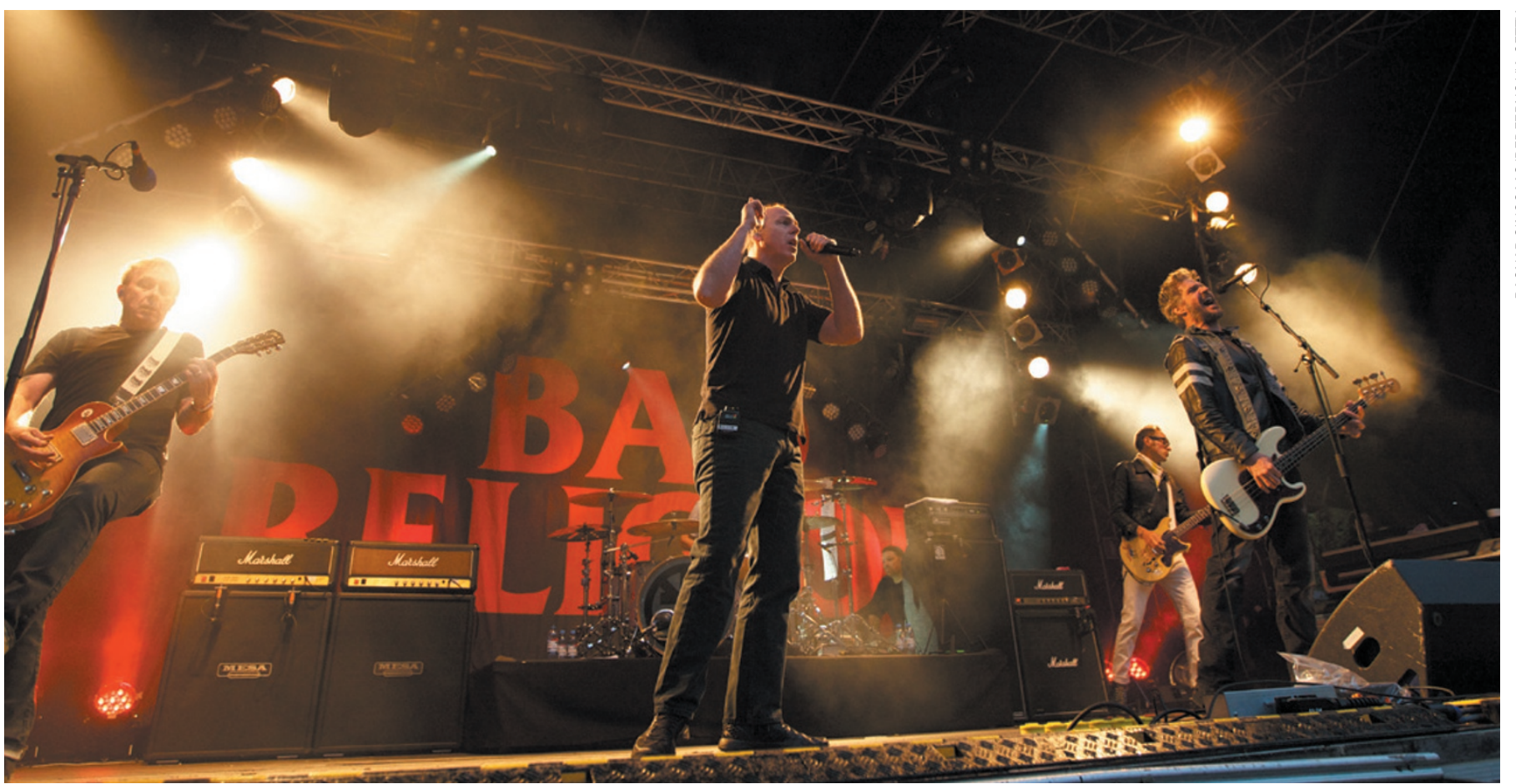

The band Bad Religion is fronted by evolution researcher Greg Graffin.

\title{
SCIENCE AND THE ARTS
}

\section{Rock and research}

\section{Scientists who moonlight as musicians get more from a gig than a fistful of cash.}

\section{BY KAREN KAPLAN}

cientists are used to facing the music.

$\mathrm{S}$ Failure stares them down every time their grant is denied, their paper is rejected, their fellowship is declined or their experiment flops.

But many deal with the anguish of figuratively facing the music by literally making it. Although no formal statistics document the number of researchers who are professional or amateur musicians, anecdotal evidence suggests that they are legion. Those who cultivate a second life as musicians say that the misery of failed experiments, vetoed grant applications and rebuffed manuscripts falls away whenever they pick up their guitar, trumpet or drumsticks.

One might wonder why early-career researchers - who typically work 70-80-hourplus weeks - spend what little spare time they have rehearsing, performing and recording music when they could be, say, sleeping, or spending that time with their family. In part, say scientist-musicians, it is because performing live onstage or setting down tracks in the studio is akin to a powerfully addictive drug: it gives them such a rush that they must keep coming back for more. Indeed, research has confirmed that creating, performing and listening to music produces dopamine, the same neurochemical released during sex and other such pleasurable experiences (V. N. Salimpoor et al. Nature Neurosci. 14, 257-262; 2011). But scientistmusicians also say that making music helps them to unwind and recalibrate. Rumination, recrimination or self-flagellation about what went wrong with the research programme or why the tenure application was turned down disappears when they focus on the next note or chord and the audience's response.

It has another advantage, too. For many who pursue music, it feeds and bolsters their science. Freeing their mind from the tightly structured rigours of an experiment and the tedium of data collection to wander through fields of melodies and measures nurtures their scientific creativity. Days, even hours, after a particularly satisfying performance, writing stint or rehearsal session, a researcher often finds that she or he can suddenly devise a better way to approach a study, develop a stronger hypothesis for a manuscript or come up with a different rationale for a grant.

There is, of course, another, more fundamental reason for the time sacrifice: performing music onstage, writing and even rehearsing it is great fun.

"You get obsessed with it," says Joseph LeDoux, a neuroscientist at New York University and singer-songwriter and guitarist for blues-rock band The Amygdaloids, who perform at clubs and other venues and have 
> recorded two original CDs and an extended play. "A lot of what I do for the band is write, and I'm a decent writer. It's not the same kind of writing as a paper or a grant, but it's freeing and releasing to write that way."

The immediate audience feedback is a huge part of live music's allure and a counterpoint to science's slower pace, says Cliff Schweinfest, scientific review officer for the US National Cancer Institute in Rockville, Maryland, and trumpet player for the NIH Community Orchestra, a volunteer group of classical and Renaissance musicians whose day jobs are with the US National Institutes of Health (NIH) and other federal agencies. "Music gives you an instantaneous pay-off," he says. "That's very satisfying - it's a good complement to science, which has a much slower pace."

The music-science interplay can have real benefits. One study, for instance, has found that people who form companies and file patents are much more likely to be involved in the arts than are those who have never done these things (R. LaMore et al. Econ. Dev. Q. 27, 221-229; 2013). Long-term participation may enhance creative potential in science and technology, and scientists who are musicians are likely to be highly successful, publishing provocative papers or producing many patentable inventions, says psychologist Robert Root-Bernstein from Michigan State University in East Lansing, and an author of the study. "They are more successful by any set of criteria, including publishing and grants," he says. "They are more innovative. A lifelong exposure to music helps to foster a more creative approach to work."

\section{BLURRED BOUNDARIES}

So tightly intertwined are science and music for evolutionary researcher Greg Graffin, who fronts the punk-rock outfit Bad Religion in Los Angeles, California, that the lines between them often blur. Lead singer and songwriter for the band since he was 15, Graffin perceives a profound connection between the anti-establishment, alienative nature of punk music and the demands of scientific research for rational thinking and for challenging existing doctrine. The mindset has piloted both his science and his music for the past 35 years. "That was the way I was thinking when I was 16 - to challenge authority to make headway in this world," he says. "It's worked for me in punk, and it's what I do as a scientist." Of the four books he has published, Anarchy Evolution: Faith, Science, and Bad Religion in a World Without God is perhaps the most iconoclastic, examining the conflict between religion and science.

Hugely successful as a punker - Bad Religion headlined iconic clubs such as Whiskey a Go-Go in West Hollywood, California, when he was 17 - Graffin slowed his research career for a while, fitting in a doctorate, a postdoc and stints at the bench between tours and records. But he could never bring himself to leave science completely for music, lucrative though his

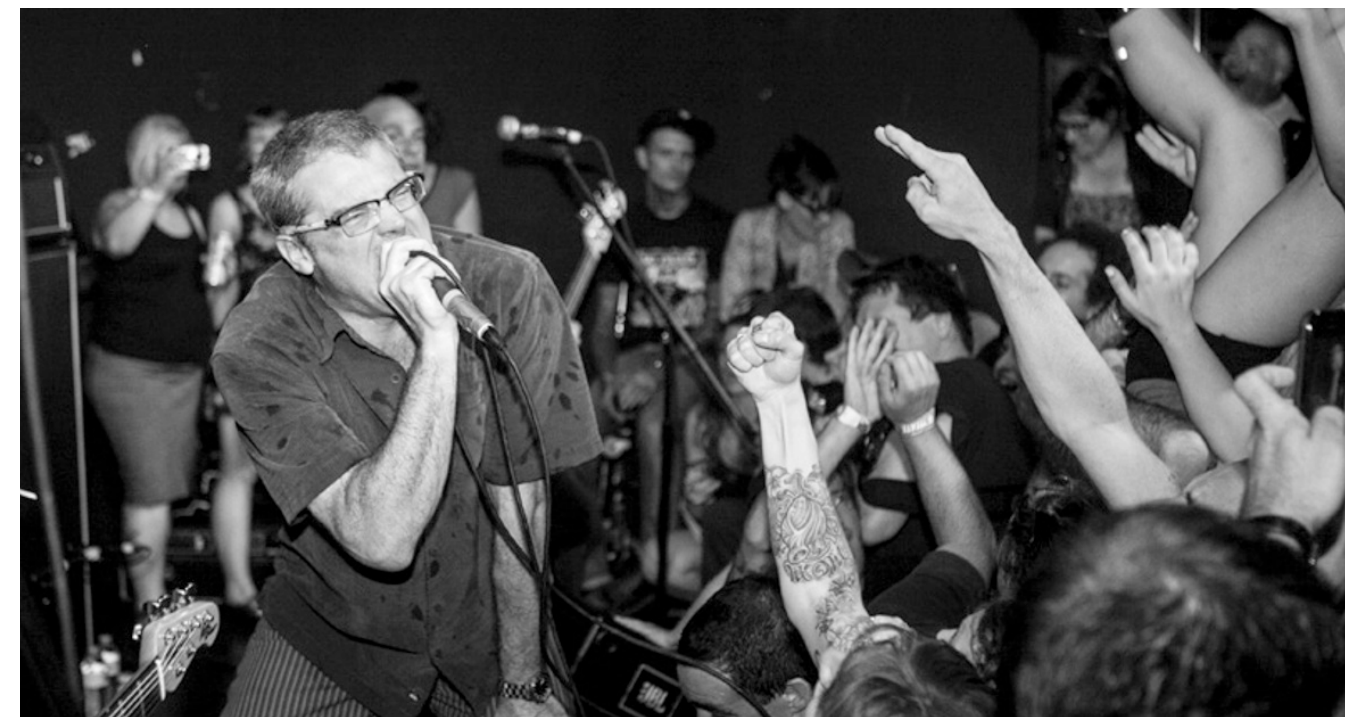

Punk band the Descendents release albums around research and family commitments.

music career has been. He is now a lecturer in evolution at Cornell University in Ithaca, New York, and is preparing to publish a book on the biological basis of species coexistence. He teaches and conducts research in the autumn and spring, and reserves summers for touring, writing and recording - because even now, decades later, music still holds a seductive allure.

"To this day, there's nothing more rewarding than playing concerts and just seeing the people mouth the words and sing along," he says. "There's such a dichotomy - the lights, the stage, the sensation of the moment - and the inverse of that, the quiet solitary work of data collection."

Although his music and his science are closely knit in his mind, Graffin tries to keep them separate, especially for his students, in an effort to preserve his scientific identity. "In a lecture, I don't even talk about music, but [students] come up after class," he says. "I don't want to promote that part of my life - in a sense they're indulging me, to see me as a scientist. I'm walking the line between the two worlds."

Plant geneticist Milo Aukerman also straddles an oft-indistinct boundary between research and music. Long-time frontman and lead singer for Los Angeles-based early punkers the Descendents, Aukerman followed a path similar to Graffin's, sandwiching his graduate programme and postdoc between tours and recording sessions. After completing his postdoc in 1999 - it took six years, thanks to a series of leaves for touring and recording - Aukerman joined DuPont in Wilmington, Delaware, in 2001. Then music came knocking again. "I hadn't been at DuPont for more than a year when the band called. I said, 'I can't tour', and they said, 'How about a record?', and I said 'I could squeeze that in," he recalls. The CD was released in 2004 to significant acclaim,

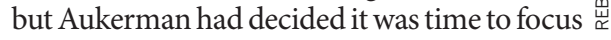
again on his science - until 2010, when the muse called him back once more. Now, he joins the band for weekend shows and brief international tours that he fits in during holidays.

\section{COMPLEMENTARY CURES}

Music and science, he says, are different sides of the same coin - they both draw on creative energies and abilities. "From the very beginning of my interest in biology, it was about what you could do. This was a raw substance, this was like something you sculpted, that you could create with," Aukerman says. "It's the same way in music. Having innovated - writing a song, interpreting a riff in a different way - brings the same exhilaration that you get from science."

And the research can inform the music. The Amygdaloids' original tunes are about the brain or the mind in some way - and LeDoux finds that the music affects his work in a positive fashion. "I've got much better at being a performer - I'm more relaxed now, more spontaneous, and that also helps flipping back to science I'm more willing to free-associate," he says, adding that being a rocker has improved his performance on the podium when he gives talks. "During a science lecture, you might be in your own mind, facing the screen, looking for the next slide, but with music, you've got to be right there - onstage as a musician, it's all about grabbing the audience. And I've become much more conscious of that in my work."

For some, the music offers more direct insights: it is part and parcel of the research itself. Thomas Scelo, an acoustics consultant and classical guitarist, knows that the connection between his music and his research is substantive, even crucial. The director of Marshall Day Acoustics in Hong Kong, Scelo works with cities, private companies, architects and others 
to create concert halls, opera houses and other performance venues in Europe, Asia and Oceania.

Scelo designs with his ear: his main objective is "to make sure the music sounds great". Although he has a doctorate in architectural acoustics and a master's in physics, he maintains that he could not do his job were he not a musician. "My job is to link science and music," says Scelo, who began playing guitar at 6 , joined a classical orchestra at 18 and has been performing in orchestras and in the occasional rock band ever since. "As a musician, I understand what musicians need on the stage so they can perform under optimum conditions," he says. "The outcome of my work is emotion. I have done good science if I see people at the end of the concert in tears."

Classical pianist and violinist Jukka Pätynen, who researches concert-hall acoustics and music processing and auralization at Aalto University in Espoo, Finland, is equally reliant on his musical life for his science. "The orchestral sound and musical content is quite familiar to me - it's one of the biggest strengths of my background for my research work," says Pätynen, who performs regularly in a regional orchestra. "Because I am a concert pianist, I know what I'm talking about when I take a room's acoustic measurements. It's quite easy to get into the details of the sound and how the orchestra would need to sound there or here, and how things sound different in different parts of a room."

Are there downsides to fitting a second life as a musician into the taxing, time-consuming career of a researcher? Only that, sometimes, the music has to take a back seat. Singer and ukulele player Ali Dreyfuss, a doctoral student in theoretical nuclear physics at Louisiana State University in Baton Rouge, gigs as often as she can with the swing-blues band Solomon Douglas Swingtet. Sometimes it is nowhere near as much as she would like - she has not travelled with them since last November, thanks to a gruelling class and research schedule combined with band dates that are not worth her while monetarily to fly out of town.

Still, Dreyfuss says that she welcomes any chance to step up onstage and immerse herself in torchy blues or high-octane swing. For her, too, music provides a way to recharge. "My work creates little bursts of activity and creativity, but as a nuclear theorist, I have to recognize all these rules and restrictions - I have to put pieces together, like a puzzle," she says. "After doing that for hours and hours and hours, you've accumulated a bunch of stress and frustration, and something needs to discharge your brain. Music gives you a different way to unplug." -

Karen Kaplan is the Careers editor for Nature.

\section{TURNING POINT Winnie Tang}

Epigeneticist Winnie Tang was one of ten US-based women to attend the fifth annual US-China Young Scientists Forum, sponsored by the US Department of State, in April. The Chinese native, who is a researcher at Johns Hopkins University in Baltimore, Maryland, explains why such events are so important for international scientists.

\section{What were your early-career ambitions?}

As an undergraduate at the Chinese University of Hong Kong, I didn't think about my career very much. I just wanted to do a $\mathrm{PhD}$ in Hong Kong, research multidrug-resistant and radiation-resistant forms of liver cancer and maybe one day become a teacher. When I started my $\mathrm{PhD}$, my adviser had just moved back to Hong Kong from a stint at Harvard University in Cambridge, Massachusetts, and encouraged his students to go to international meetings to network and to look for research opportunities. And, in fact, I met my future postdoctoral adviser - cell biologist and physiologist Shuk-mei Ho, then at the University of Massachusetts Medical School in Worcester - at a meeting of the American Association for Cancer Research.

\section{How did your US move affect your career?}

It provided more research opportunities in newer fields as well as the chance for interaction with a variety of researchers - clinicians, molecular biologists, environmental-health and cancer researchers. I realized that I wanted my own lab and to develop collaborations with other scientists.

\section{What did you work on as a postdoc?}

Epigenetics - profiling gene expression in prostate cancers. Ho encouraged me to apply for a US Department of Defense postdoctoral trainee award, in part because it is one of the few programmes available for researchers who don't have US citizenship. The fellowship was a turning point for me because it allowed me to follow Ho to the University of Cincinnati in Ohio when she became its director of environmental-health science. There, I focused on the role of environmental-chemical exposure and endocrine disruption in prostate cancer, which was more in line with my goal of doing research that was translatable to the public.

\section{How did you set about finding a job?}

Ho encouraged me to apply for a Pathways to Independence award from the US National Institutes of Health (NIH). I got it and worked for two years at the University of Cincinnati before looking for tenure-track positions at

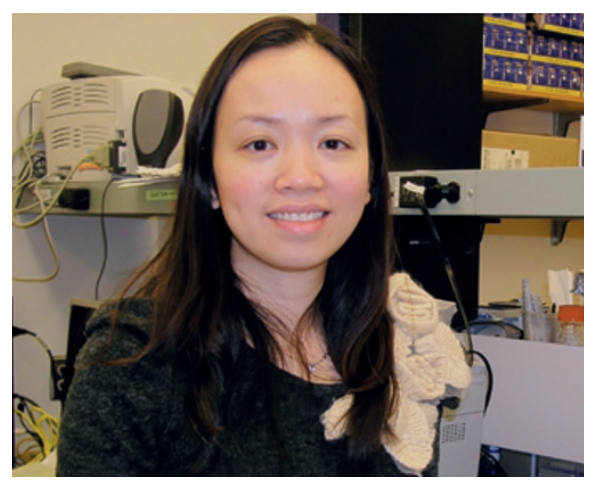

other institutes. When I saw that Johns Hopkins wanted to hire a genetics and toxicology researcher, I thought, 'Bingo'. The NIH grant made me very competitive for the position.

\section{What was your biggest challenge there?}

Learning how to be a professor: it was the first time that I had been in charge of teaching, managing budgets and mentoring students. I was overwhelmed for the first two years. Now that I'm figuring that out, I've got to secure funding. I've built a lot of collaborations here, partnering with colleagues who study the epigenetics of asthma in humans and other animals. I am now trying to get an R01 grant, the NIH's largest grant for individual investigators.

What is the US-China Young Scientist Forum? It is an annual one-day event to bring women researchers from the United States and China together. Women from China are eager for career advice on issues such as work-life balance and gender disparity in the workplace. For example, they note that their bosses often save the best opportunities for men. They also want to find possible collaborators: they want to do well in their institutes in China and are looking for ways to create opportunities there.

\section{What connections did you make there?}

I met Qian Wu, a breast-cancer researcher at Nanjing Medical University in China, and she is working in my lab as a visiting scholar for the next six months. She decided after the forum that she wanted to learn more about epigenetics so that she could open up that area of research at her home institute. Right now, US labs have a lot of visiting scholars from China because the government there has more funding for overseas trips. While funding here remains tight, this is a nice way for US scientists to forge collaborations.

\section{INTERVIEW BY VIRGINIA GEWIN}

